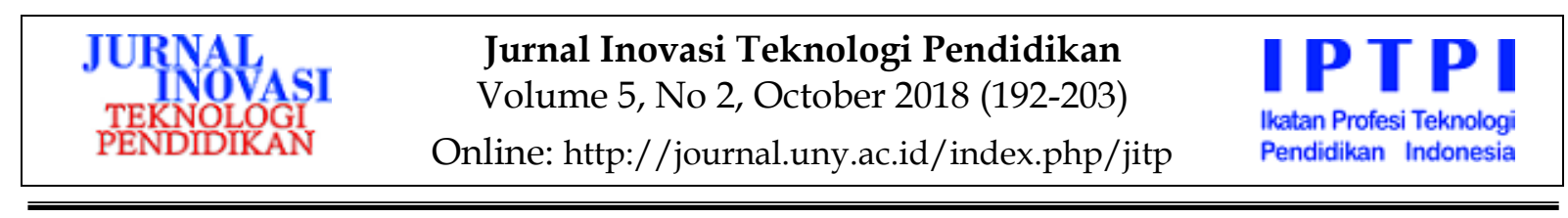

\title{
BAHAN AJAR INTERAKTIF UNTUK MENINGKATKAN PEMAHAMAN KONSEP MATEMATIKA PADA SISWA SMA KELAS $X$
}

\author{
Nurhairunnisah ${ }^{1}$, Sujarwo ${ }^{2}$ \\ 1FKIP Prodi Teknologi Pendidikan Universitas Samawa, 2Universitas Negeri Yogyakarta \\ 1J1. Bypass Sering, Kerato, Unter Iwes, Sumbawa, Nusa Tenggara Bar. 84316, Indonesia \\ 2Jl. Colombo No. 1, Depok, Sleman 55281, Yogyakarta, Indonesia \\ * Corresponding Author. Email: nurhairunn@gmail.com
}

\begin{abstract}
Abstrak
Penelitian pengembangan ini bertujuan: (1) menghasilkan bahan ajar interaktif untuk meningkatkan pemahaman konsep matematika pada siswa kelas X SMA PIRI 1 Yogyakarta, (2) menghasilkan bahan ajar interaktif yang layak untuk meningkatkan pemahaman konsep matematika siswa kelas X SMA PIRI 1 Yogyakarta, dan (3) menghasilkan bahan ajar interaktif yang efektif untuk meningkatkan pemahaman konsep matematika siswa kelas X SMA PIRI 1 Yogyakarta. Penelitian pengembangan ini mengacu pada langkah-langkah desain pengembangan yang dikembangkan oleh Alessi \& Trollip. Desain pengembangan tersebut dikelompokkan atas tiga prosedur pengembangan, yang meliputi: (a) tahap perencanaan (planning), (b) tahap desain (design), dan (c) tahap pengembangan (development). Penelitian ini (1) menghasilkan bahan ajar interaktif dalam bentuk digital yang dikemas menggunakan Compact Disk (CD) dan dilengkapi buku petunjuk yang dapat digunakan oleh siswa sebagai sumber belajar pendukung pembelajaran matematika, (2) produk yang dihasilkan dinilai sangat layak untuk meningkatkan pemahaman konsep matematika berdasarkan penilaian ahli materi, ahli media dan subyek uji coba, dan (3) produk yang dihasilkan efektif meningkatkan pemahaman konsep matematika siswa kelas X SMA PIRI 1 Yogyakarta, terbukti dengan nilai rata-rata pretest sebesar 22,65 meningkat pada posttest sebesar 74,23 dengan nilai gain skor 0,71. Kata kunci: bahan ajar interaktif, pemahaman konsep, siswa SMA kelas X.

\section{INTERACTIVE LEARNING MATERIAL TO IMPROVE UNDERSTANDING OF MATHEMATICAL CONCEPTS IN HIGH SCHOOL STUDENTS OF CLASS $X$}

Abstract

This developmental research aims to: (1) produce an interactive learning material product for improving understanding of mathematical concepts of grade X students of SMA PIRI 1 Yogyakarta, (2) generate viable interactive learning materials for improving understanding of mathematical concepts of grade X students of SMA PIRI 1 Yogyakarta, and (3) generating interactive effective learning materials for improving understanding of mathematical concepts of grade X students of SMA PIRI 1 Yogyakarta. This research refers to the developmental phases developed by Alessi $\mathcal{E}$ Trollip. The developmental design was grouped into three development procedures, consisting of: (a) planning, (b) design, and (c) development. The research (1) produces interactive learning materials in digital form which are packed in Compact Disk (CD) and comes with manuals that can be used by students as learning resources supporting mathematics learning, (2) the product is considered highly feasible to improve the understanding of mathematical concepts based on the assessment of material experts, media experts, and subject trials, and (3) the product effectively improves the understanding of mathematical concepts of grade X students of SMA PIRI 1 Yogyakarta, as evidenced by the pretest average value of 22.65 increases in posttest to 74.23 with gain score value of 0.71 .
\end{abstract}

Keywords: interactive learning materials, conceptual understanding, high school students of class X

Permalink/DOI: http://dx.doi.org/10.21831/jitp.v5i2.15320 


\section{Pendahuluan}

Pendidikan pada era teknologi saat ini mengharuskan para guru dapat mengoperasikan komputer/laptop dan melakukan inovasi agar dapat memberikan suasana baru dalam lingkungan belajar. Pendidikan seharusnya bisa dijadikan pondasi agar pemanfaatan teknologi dapat diterapkan secara efektif oleh guru sebagai penyalur pendidikan (Haryanto, 2015, p. 167).

Upaya pemerintah untuk meningkatkan kualitas pendidikan dilakukan secara terus menerus terlihat beberapa kali perubahan pada kurikulum. Upaya pemerintah yang lain terlihat pada Undang-Undang Nomor 20 Tahun 2003 tentang Sistem Pendidikan Nasional. Undang-Undang ini mampu menjamin peningkatan mutu pendidikan saat ini, salah satu upaya yang dilakukan adalah melalui peningkatan kualitas pembelajaran. Pembelajaran merupakan proses interaksi antara siswa dan guru di lingkungan belajar (Presiden Republik Indonesia, 2003).

Berdasarkan Peraturan Pemerintah Nomor 19 Tahun 2005 pasal 19 ayat 1 (Presiden Republik Indonesia, 2005), dalam pembelajaran diharapkan pendidik dapat menggunakan metode maupun media yang mampu melibatkan siswa secara aktif dan menciptakan suasana menyenangkan, menarik, dan interaktif yang disesuaikan dengan tahap perkembangan berfikir, karakteristik dan kondisi belajar siswa. Kondisi ini juga sangat diperlukan pada pembelajaran matematika di SMA.

Matematika merupakan salah satu mata pelajaran yang dipelajari dari tingkat Sekolah Dasar sampai ke Perguruan Tinggi. Mata pelajaran tersebut memiliki tujuan agar siswa dapat memahami konsep matematika, menjelaskan hubungan antarkonsep dan menerapkan konsep tersebut secara akurat dan efisien dalam pemecahan masalah Ibrahim \& Suparni (2008, p. 36). Berdasarkan pendapat tersebut salah satu kemampuan yang harus dikuasai siswa dalam pembelajaran matematika adalah memahami konsep matematika dalam me- mecahkan suatu masalah. Oleh karena itu, berhasilnya suatu pembelajaran matematika dapat ditunjukkan jika siswa mampu memahami dan menguasai suatu konsep yang disajikan.

Untuk mewujudkan tujuan tersebut seorang guru harus memiliki keterampilan dalam memilih, menggunakan metode pembelajaran yang baik dan jenis media yang digunakan agar dapat mendukung pemahaman siswa terhadap konsep yang disajikan. Menurut Sudjana \& Rivai (2002, p. 2) penggunaan media pada pembelajaran dapat membangkitkan proses berfikir siswa dari berfikir konkret menuju ke berfikir abstrak. Namun, pelaksanaan pembelajaran matematika yang terjadi di kelas X SMA Piri 1 Yogyakarta selama ini guru belum menggunakan media komputer. Penggunaan bahan ajar yang bervariasi dapat dilakukan dalam menciptakan pembelajaran yang baik (Purmadi \& Surjono, 2016, p. 152). Pembelajaran matematika di kelas masih menggunakan metode ceramah, tanya jawab, dan penugasan. Hal ini mengakibatkan kurangnya motivasi belajar siswa sehingga siswa jenuh dan kesulitan dalam memahami materi belajar.

Berdasarkan hasil observasi yang dilakukan di SMA Piri 1 Yogyakarta, bahan ajar yang digunakan guru maupun siswa pada proses pembelajaran di kelas berupa Lembar Kerja Siswa (LKS) dan buku pendukung lainnya yang disediakan oleh sekolah. Pada umumnya LKS yang digunakan tidak interaktif karena komunikasi hanya satu arah dan struktur LKS hanya berisi ringkasan materi, kumpulan rumus-rumus, contoh soal, dan latihan soal. Pola tersebut memberikan pandangan sempit pada siswa tentang materi pelajaran matematika karena baik materi, contoh soal, dan latihan soal yang disajikan dikatakan minim penjelasan.

Salah satu guru kelas $\mathrm{X}$ menyatakan bahwa ketika pembelajaran berlangsung siswa kurang antusias dan kesulitan dalam memahami meteri pelajaran yang membutuhkan visualisasi ataupun bersifat abstrak seperti yang terdapat pada materi dimensi tiga. Ruang dimensi tiga adalah salah satu 
materi yang mempelajari tentang kedudukan garis, garis, jarak, dan besar sudut dalam ruang (Sartono, 2006, p. 266). Karakteristik materi dimensi tiga tersebut membutuhkan tingkat pemahaman konsep yang lebih tinggi dibandingkan dengan materi lainnya. Menurut Kariadinata (2010, p. 11), pemecahan masalah dalam materi bangun ruang dimensi tiga diperlukan visualisasi, sehingga siswa dapat mengkomunikasikan kembali sebuah konsep yang telah dipelajarinya. Namun, selama ini bahan ajar yang digunakan, dikemas dalam bentuk tidak interaktif dan tidak lengkap, sehingga diperlukan sebuah bahan ajar yang mampu menjelaskan materi secara lebih rinci, memvisualisasi materi yang abstrak, melatih siswa untuk berfikir kreatif serta mampu memecahkan masalah. Salah satu cara yang dapat dilakukan oleh guru adalah mengembangkan media pembelajaran berupa bahan ajar (Lasmiyati \& Harta, 2014, p. 162). Pengembangan bahan ajar pada proses pembelajaran perlu dilakukan, agar terciptanya pembelajaran yang efektif dan efisien (Lukman \& Ishartiwi, 2014, p. 111). Bahan ajar adalah seperangkat materi dan sumber daya yang membantu guru dan siswa dalam pembelajaran (Ifeoma, 2013, p. 8). Lebih lanjut Widodo \& Jasmandi (2008, p. 4) menyatakan bahwa bahan ajar merupakan seperangkat sarana pembelajaran yang di dalamnya terdapat materi, metode, batasanbatasan, dan cara mengevaluasi yang didesain secara menarik agar tercapainya tujuan pembelajaran. Mudlofir (2011, p. 128) berpendapat bahwa bahan ajar adalah seperangkat materi yang disusun secara hirarki, baik berupa bahan tertulis maupun tidak tertulis yang dapat digunakan dalam proses pembelajaran. Penggunaan bahan ajar dapat meningkatkan hasil belajar siswa (Effiong \& Igiri, 2015, p. 27). Berdasarkan beberapa pendapat tersebut dapat disimpulkan bahwa bahan ajar merupakan alat untuk belajar yang memuat seperangkat materi, metode, latihan, dan evaluasi sebagai pendukung tercapainya tujuan pembelajaran. Salah satu bahan ajar yang dirasa dapat membantu siswa maupun guru da- lam mengatasi masalah tersebut yaitu modul pembelajaran interaktif.

Menurut Goldshmid \& Goldshmid (Sukiman, 2012, p. 68), Modul adalah "A self-contained, independent unit of a planned series of learning activities designed to help the student accomplish certain well-defined objectives". Modul merupakan unit kegiatan belajar mandiri yang digunakan sebagai alat bantu belajar oleh siswa (Guido, 2014, p. 1127). Dari beberapa pandangan tersebut maka definisi modul dalam penelitian ini adalah seperangkat bahan ajar yang didesain secara lengkap yang dapat digunakan untuk membantu peserta didik dalam belajar baik secara mandiri maupun dengan bimbingan guru untuk mencapai tujuan pembelajaran yang telah ditetapkan.

Interaktif menurut Munir (2015, p. 65) adalah proses komunikasi dua arah atau lebih dari elemen-elemen komunikasi itu sendiri. Definisi lain yang dikemukakan oleh Prastowo (2011, p. 329) menyatakan bahwa interaktif adalah suatu yang bersifat aktif, maksudnya didesain dapat melakukan perintah kepada siswa untuk melakukan suatu perintah. Bentuk interaktif dalam penelitian ini adalah melakukan suatu perintah seperti siswa dapat berpindah halaman, memutar, menjeda baik video maupun animasi (Nugent et al., 2016, p. 114).

Modul pembelajaran interaktif yang akan dikembangkan, dilengkapi dengan berbagai format konten pembelajaran seperti teks, gambar, animasi, dan video yang dapat digunakan sebagai sumber belajar yang tepat untuk materi dimensi tiga. Melalui modul tersebut, tentunya mereka akan terbantu dalam menguasai kompetensi dari materi dimensi tiga. Siswa lebih termotivasi dengan menggunakan modul (Mawarni \& Muhtadi, 2017, p. 88). Selain itu, penggunaan bahan ajar berupa modul pembelajaran interaktif ini dapat dibaca pada komputer maupun laptop, sehingga bahan ajar ini bersifat lebih praktis dan memiliki kontenkonten pembelajaran yang memudahkan siswa belajar dibandingkan dengan bahan ajar lainnya (modul cetak, LKS dan buku). 
Bahan ajar berupa modul yang apabila dikembangkan (inovasi) sendiri oleh guru dapat disesuaikan dengan kebutuhan, karakteristik, dan tahap perkembangan siswa sehingga dapat mencapai tujuan pembelajaran. Menurut Fajarini, Soetjipto, \& Hanurawan (2016, p. 62), salah satu bahan ajar yang disusun secara sistematis untuk siswa agar mudah dipahami sesuai dengan tingkat pengetahuan dan usianya, serta siswa dapat belajar mandiri yaitu modul. Menurut Departemen Pendidikan Nasional (2008, p. 13), pengembangan modul dapat memecahkan kesulitan belajar. Kesulitan tersebut dapat saja terjadi karena materi tersebut bersifat abstrak dan memiliki tingkat kerumitan yang sulit dipecahkan oleh siswa. Artinya penggunaan modul pembelajaran interaktif berbasis digital dapat belajar dengan mandiri disesuaikan dengan kebutuhan belajar masing-masing siswa. Berdasarkan uraian di atas, peneliti merasa perlu mengembangkan bahan ajar interaktif untuk meningkatkan pemamahan konsep matematika pada siswa SMA kelas X.

Pemahaman menurut Bloom (Degeng, 2013, p. 203) adalah perubahan bentuk informasi dari yang sulit ke mudah, agar mudah dipahami oleh siswa. Lebih lanjut Hernawan, Susilana, Julaeha, \& Sanjaya (2011, p. 24), pemahaman adalah kemampuan menafsirkan arti dari suatu konsep seperti gambar, grafik atau bagan. Jadi dapat disimpulkan bahwa pemahaman seorang siswa dikatakan paham jika siswa mampu mendefinisikan, mengidentifikasi, mendeskripsikan, menghitung dan mampu menyimpulkan bentuk-bentuk materi yang sulit dengan kalimatnya sendiri.

Konsep menurut Merrill (1994, p. 23), adalah sekelompok objek, peristiwa atau simbol-simbol yang memiliki ciri yang sama dan diidentifikasi dengan nama yang sama. Konsep matematika harus disusun secara hirarkis, untuk itu dalam mempelajari matematika tidak boleh ada langkah konsep yang terlewati (Herawati, R., \& Basir, 2010, p. 71). Lebih lanjut menurut Bruner (Degeng, 2013, p. 115), menyatakan bahwa jika siswa memahami suatu konsep, maka mereka harus mampu mengetahui semua unsur konsep yang meliputi nama, contoh-contoh baik yang positif dan negatif, karakteristik, rentangan karakteristik dan kaidah. Konsep merupakan gambaran dari suatu ide abstrak yang di dalamnya mewakili stimuli (nama, objek, peristiwa, simbol, kaidah) yang memiliki karakteristik dan nama yang sama. Apabila Siswa yang tidak mampu menguasai konsep dasar matematika, maka akan kesulitan mempelajari konsep selanjutnya. Siswa yang memiliki tingkat pemahaman baik, akan mampu menjelaskan suatu konsep-konsep matematika sesuai apa yang dipahaminya.

Pemahaman konsep dapat menciptakan pembelajaran menjadi lebih bermakna sehingga berhasilnya suatu pembelajaran matematika. Menurut National Council of Teachers of Mathematics (2000, p. 21) bahwa Pemahaman konsep merupakan komponen penting dalam pembelajaran matematika. Kemudian menurut Kilpatrick \& Swafford (2001, p. 116), pemahaman konsep adalah kemampuan memahami konsep, operasi dan relasi matematika. Pemahaman konsep menurut Jihad \& Haris (2008, p. 149), merupakan kompetensi yang muncul dari siswa dalam memahami konsep secara luwes, akurat, efisien dan tepat.

Pemahaman konsep dalam bahan ajar interaktif tidak hanya diukur dengan mengerjakan/menjawab soal pretest maupun posttest, akan tetapi diukur juga melalui kemampuan dalam mengerjakan soal latihan pada tiap kegiatan pembelajaran. Jika siswa mampu menjawab soal latihan dengan baik berarti siswa telah memahami konsep tersebut dan dapat melanjutkan ke kegiatan pembelajaran selanjutnya.

Penelitian ini dibatasi pada masalah minimnya bahan ajar interaktif yang dapat memvisualisasi materi yang bersifat abstrak, sehingga pemahaman siswa masih perlu ditingkatkan. Berangkat dari masalah tersebut maka penelitian ini difokuskan pada pengembangan bahan ajar interaktif untuk meningkatkan pemahaman konsep matematika pada siswa SMA kelas $X$ di SMA PIRI 1 Yogyakarta. Adapun rumusan 
masalah yang diteliti sebagai berikut: (1) Bagaimana bentuk bahan ajar interaktif untuk meningkatkan pemahaman konsep matematika pada siswa kelas X SMA PIRI 1 Yogyakarta, (2) Apakah bahan ajar interaktif layak untuk meningkatkan pemahaman konsep matematika siswa kelas X SMA PIRI 1 Yogyakarta, dan (3) Apakah bahan ajar interaktif efektif untuk meningkatkan pemahaman konsep matematika siswa kelas X SMA PIRI 1 Yogyakarta.

\section{Metode Penelitian}

Jenis penelitian yang digunakan adalah penelitian R\&D (Riset \& Development). Penelitian ini dilaksanakan pada bulan April-Mei 2017 di SMA PIRI 1 Yogyakarta. Subyek/responden yang terlibat dalam penelitian ini adalah siswa kelas XI berjumlah 6 siswa pada uji beta 1 dan 32 siswa kelas $X$ pada uji beta 2 .

Model pengembangan produk bahan ajar interaktif dalam penelitian ini diadaptasi dari Alessi \& Trollip (2001, p. 410) Alessi \& Trollip (2001, p.410) yang terdiri dari tiga prosedur yaitu tahap perencanaan (planning), tahap desain (design), dan tahap pengembangan (development).

Tahap perencanaan dalam penelitian ini adalah mendefinisikan ruang lingkup (define the scope). Ruang lingkup materi yang disajikan dalam bahan ajar interaktif adalah materi ruang dimensi tiga untuk siwa kelas $X$. Selanjutnya mengidentifikasi karakteristik siswa. Karakteristik siswa diperoleh dari hasil observasi, wawancara dengan guru, dan teori pendukung lainnya. Pada tahap desain, mengembangkan semua ide yang telah direncanakan pada tahap perencanaan, menentukan materi dan mengorganisasikan materi agar mudah dilihat, selanjutnya mulai dikembangkan flowchart dan storyboard. Pada tahap pengembangan berkaitan dengan aktivitas menyiapkan semua kompenen serta konten-konten yang disajikan dalam bahan ajar interaktif. Komponen yang telah diproduksi kemudian digabung /dipadu menjadi satu kesatuan sehingga mengahasilkan produk bahan ajar inter- aktif. Selanjutnya untuk menilai kelayakan produk dilakukan uji coba yang terdiri dari dua tahap, yaitu uji alpa dan uji beta. Uji alpa dilakukan oleh 2 ahli materi dan 2 ahli media untuk menilai kelayakan konten dan media. Uji beta dilakukan oleh 6 siswa kelas XI pada uji beta 1 dan 32 siswa kelas X pada uji beta 2 .

Teknik pengumpulan data yang digunakan dalam penelitian ini adalah pedoman wawancara, observasi, angket, dan tes. Sedangkan instrumen yang digunakan adalah angket dan tes berupa pretest dan posttest. Instrumen angket terdiri dari tiga jenis yaitu angket untuk ahli materi, angket untuk ahli media, dan angket untuk respon siswa yang digunakan untuk menilai kelayakan produk sebelum digunakan oleh user (siswa kelas X). Pedoman penilaian angket menggunakan empat skala penilaian sebagai berikut: "sangat baik" (4), "Baik" (3), "Kurang" (2), dan "Sangat Kurang" (1).

Teknik analisis data dalam penelitian ini diperoleh dari instrumen penelitian berupa data kualitatif dan kuantitatif. Data kuantatif diperoleh dari angket dan data kualitatif diperoleh dari respon atau saran dari ahli dan siswa setelah menggunakan bahan ajar interaktif. Teknik analisis data untuk kelayakan media menggunakan analisis data deskriptif, maka digunakan pedoman skala penilaian instrumen dan kriteria penilaian instrumen yang dapat dilihat pada Tabel 1 dan 2 (Mardapi, 2008, p. 123) sebagai berikut:

Tabel 1. Kriteria Peniliaan

\begin{tabular}{cl}
\hline Rentang Skor & Kriteria \\
\hline$X \geq M+\mathrm{SBi}$ & Sangat Layak \\
$M+\mathrm{SBi}>X \geq M$ & Layak \\
$M>X \geq M-1 \mathrm{SBi}$ & Kurang Layak \\
$X<M-1 \mathrm{SBi}$ & Sangat Kurang Layak \\
\hline
\end{tabular}

Tabel 2. Kriteria Penilaian Pemberian Skor

\begin{tabular}{cl}
\hline Rentang Skor & Kriteria \\
\hline$X \geq 3,0$ & Sangat Layak \\
$3,0>X \geq 2,5$ & Layak \\
$2,5>X \geq 2,0$ & Kurang Layak \\
$X<2,0$ & Sangat Kurang Layak \\
\hline
\end{tabular}


Dalam penelitian ini nilai kelayakan bahan ajar interaktif ditentukan dengan nilai minimal "L" dengan kategori Layak. Jadi apabila hasil penilaian oleh ahli media, ahli materi dan respon siswa reratanya memberikan nilai akhir "L", maka produk pengembangan bahan ajar interaktif layak digunakan.

Selanjutnya untuk memperoleh data tentang efektivitas produk bahan ajar interaktif dalam meningkatkan pemahaman konsep matematika dapat diketahui dari hasil prestest dan posttest. Peningkatan hasil belajar siswa yang diperoleh sebelum dan sesudah menggunakan bahan ajar interaktif, diperhitungkan menggunakan rumus $N$ gain ditentukan berdasarkan rata-rata gain. Skor gain (g) yang diperoleh merupakan hasil dari perbandingan antara rata-rata nilai pretest dan posttest. Rata-rata gain yang dibandingkan (N-gain) (Hake, 1998, p. 65) dinyatakan dalam persamaan berikut:

$$
g=\frac{S \text { post }-S \text { pre }}{S \text { maks }-S \text { pre }}
$$

Keterangan:

$S$ post : Rata-rata skor Post-test

S pre : Rata-rata skor Pre-test

$S$ maks : Skor maksimal

Selanjutnya apabila nilai tersebut diperoleh maka langkah selanjutnya nilai tersebut dikonversikan ke dalam interpretasi nilai gain (Hake, 1998, p.3) seperti pada Tabel 3.

Tabel 3. Interpretasi Nilai Gain

\begin{tabular}{cc}
\hline Rentang Skor & Kriteria \\
\hline (N-gain) $\geq 0,7$ & Tinggi \\
$0,7>(\mathrm{N}$-gain $) \geq 0,3$ & Sedang \\
$(\mathrm{N}$-gain $)<0,3$ & Rendah \\
\hline
\end{tabular}

\section{Hasil Penelitian dan Pembahasan}

Pada penelitian dan pengembangan ini menghasilkan produk berupa aplikasi bahan ajar interaktif pada mata pelajaran matematika SMA. Proses pengembangan melalui tiga tahap yaitu tahap perencanaan, tahap desain, dan tahap pengembangan. Pada tahap perencanaan menghasilkan ruang lingkup. Hasil penelitian disajikan dalam bentuk grafik, tabel, atau deskriptif. Analisis dan interpretasi hasil ini diperlukan sebelum dibahas.

Pada tahap uji alpa penilaian yang dilakukan oleh dua ahli materi, diperoleh rerata skor secara keseluruhan terhadap lima aspek adalah sebesar 3,15 yang secara kualitatif dikategorikan "Sangat Layak" (X $\geq 3,0$ ). Rerata skor penilaian pada aspek pendahuluan adalah sebesar 3,25; aspek isi sebesar 3,08; aspek pembelajaran 3,12; aspek rangkuman 3,17; dan aspek tugas/latihan sebesar 3,14. Hasil penilaian kelima aspek oleh 2 ahli materi secara visual dapat dilihat pada diagram Gambar 1.

Pada tahap uji alpa penilaian yang dilakukan oleh dua ahli media, diperoleh rerata skor secara keseluruhan yaitu 3,22 secara kualitatif dikategorikan "Sangat Layak" $(X \geq 3,0)$. Rerata skor penilaian pada aspek tampilan adalah sebesar 3,42; aspek penggunaan sebesar 3,08; dan aspek pemanfaatan sebesar 3,17; Hasil penilaian ketiga aspek oleh 2 ahli media secara visual dapat dilihat pada diagram Gambar 2.

Pada tahap uji beta, penilaian uji beta 1 oleh 6 orang siswa dapat disimpulkan bahwa produk bahan ajar interaktif ini sangat layak digunakan untuk uji beta 2 (uji kelompok besar) sesuai dengan revisi yang disarankan. Rerata skor keseluruhan dari ketiga aspek tersebut adalah 3,22 yang secara kualitatif dikategorikan "sangat layak" $(X \geq 3,0)$. Rerata skor penilaian pada aspek pembelajaran adalah sebesar 3,28; aspek tampilan sebesar 3,17; dan aspek pemrograman sebesar 3,25; Hasil penilaian ketiga aspek oleh uji beta 1 secara visual dapat dilihat pada diagram Gambar 3.

Pada tahap uji beta, penilaian yang dilakukan oleh uji beta 2 dapat disimpulkan bahwa produk bahan ajar interaktif dikatakan "Sangat Layak" dengan rerata skor keseluruhan adalah 3,19 yang secara kualitatif termasuk dalam kategori sangat layak $(X \geq$ $3,0)$. Rerata skor penilaian pada aspek pembelajaran adalah sebesar 3,17; aspek tampilan sebesar 3,19; dan aspek pemrograman sebesar 3,21; Hasil penilaian ketiga aspek 
oleh uji beta 1 secara visual dapat dilihat pada diagram Gambar 4.

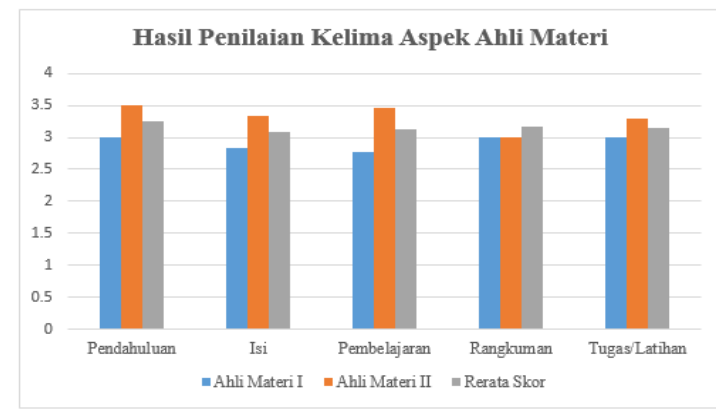

Gambar 1. Diagram Batang Hasil Penilaian Ahli Materi

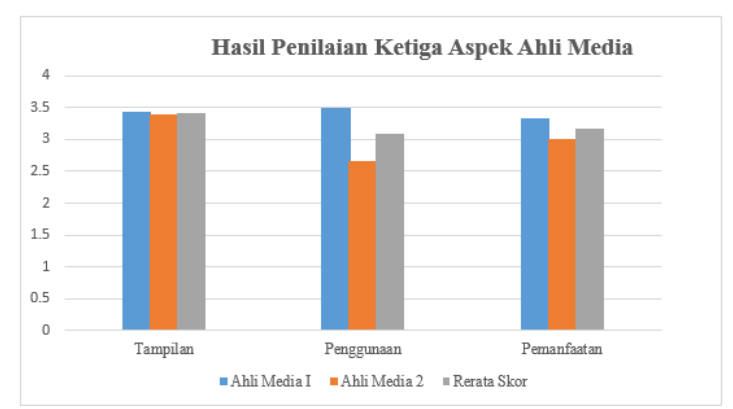

Gambar 2. Gambar 2. Diagram Batang Hasil Penilaian Ahli Materi

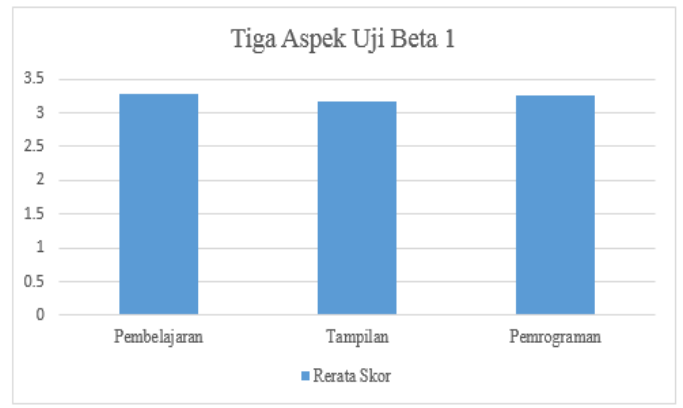

Gambar 3. Diagram Batang Hasil Penilaian Uji Beta 1

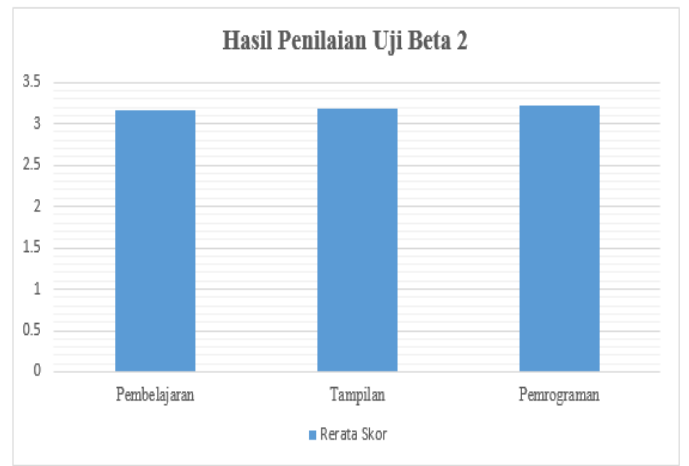

Gambar 4. Diagram Batang Hasil Penilaian Uji Beta 2
Untuk menilai tingkat efektivitas produk bahan ajar interaktif dalam meningkatkan pemahaman konsep matematika siswa, digunakan instrumen tes. Tes diberikan terdiri dari dua tahapan yaitu pretest dan posttest. Rerata skor pretest diperoleh sebesar 22,65 dan rerata skor posttest sebesar 74,23 . Hal tersebut menunjukkan peningkatan. Selain dilihat dari rata-rata yang diperoleh dari prestest dan posttest juga dilihat dari gain skor yakni sebesar 0,71 dengan kategori "Tinggi" (N-Gain $\geq 0,7)$. Peningkatan terhadap nilai rata-rata posttest menunjukkan bahwa secara umum bahan ajar interaktif efektif meningkatkan pemahaman konsep matematika setelah siswa menggunakan produk dalam pembelajaran. Soal pretest dan posttest yang digunakan memiliki bahasa soal dan jumlah butir yang sama yaitu terdiri dari 14 butir soal. Dari 14 butir soal tersebut diwakili oleh 8 indikator soal. Adapun perbedaan rata-rata skor pretest dan posttest pada tiap butir soal disajikan pada gambar 5 sebagai berikut.

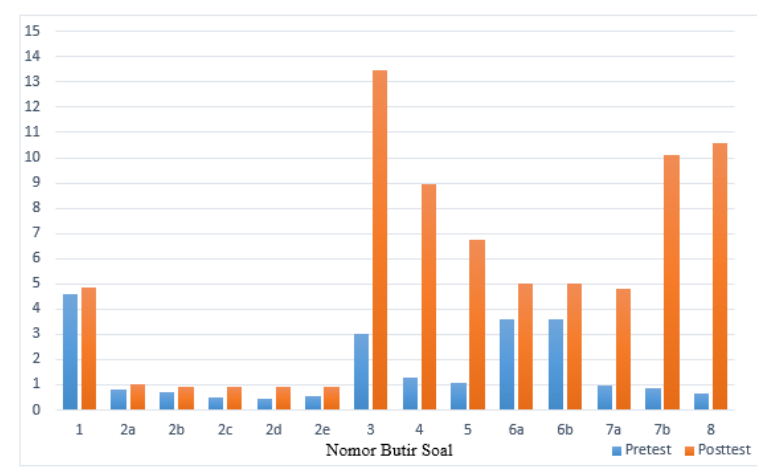

Gambar 5. Diagram Hasil Perbandingan Skor Rata-rata Prestest dan Posttest

\section{Kajian Produk Bahan Ajar Interaktif}

Proses pengembangan produk bahan ajar interaktif sesuai dengan langkahlangkah pengembangan model Allesi \& Trollip (2001, p. 410) melalui tiga tahapan yaitu planning, design, dan development. Produk akhir yang dihasilkan berupa aplikasi bahan ajar interaktif dengan format .exe dan .html yang dapat dibaca pada layar komputer/laptop dengan operasi sistem Windows. 
Produk bahan ajar interaktif dikembangkan didasarkan pada analisis kebutuhan di SMA PIRI 1 Yogyakarta. Analisis kebutuhan diperoleh dari hasil observasi awal, dan wawancara dengan guru dan siswa. Informasi yang diperoleh ketika observasi awal yaitu pembelajaran di kelas menggunakan bahan ajar cetak seperti LKS ataupun buku. Bahan ajar yang digunakan minim penjelasan karena hanya berisi ringkasan materi, kumpulan rumus, latihan soal, tidak menarik dan belum interaktif. Berdasarkan wawancara dengan guru, siswa kesulitan dalam memahami materi yang bersifat abstrak dan membutuhkan visualisasi seperti pada materi dimesi tiga. Kesulitan tersebut diakibatkan kurangnya pemahaman konsep siswa. Pemecahan masalah dalam ruang dimensi tiga diperlukan visualisasi, sehingga siswa dapat mengkomunikasikan kembali sebuah konsep yang telah dipelajarinya (Kariadinata, 2010, p. 11).

Hasil wawancara dengan siswa diperoleh bahwa siswa membutuhkan bahan ajar yang membutuhkan gambar yang menarik dan animasi. Oleh karena itu, produk bahan ajar interaktif diharapkan dapat menjadi salah satu alternatif yang dapat memudahkan siswa dalam memahami konsep yang disajikan. Ruang lingkup materi yang dikembangkan adalah ruang dimensi tiga yang terdiri dari (1) kedudukan titk, garis, dan bidang, (2) menentukan jarak dalam ruang, dan (3) sudut dalam ruang dimensi tiga. Untuk memudahkan visualisasi materi, bahan ajar interaktif siswa dikemas dalam bentuk digital. Tujuannya adalah siswa dapat mengkontrol sendiri baik navigasi maupun materinya. Siswa dapat dengan leluasa berpindah antar halaman, menonton, menjeda, dan memutar ulang konten animasi maupun video (Nugent et al., 2016, p. 114).

Produk bahan ajar interaktif yang dikembangkan diuji alpha oleh dua ahli materi dan dua ahli media yang menguasai bidangnya. Berdasarkan hasil penilaian ahli materi diperoleh rata-rata skor sebesar 3,15 dengan kategori sangat layak, sehingga materi yang disajikan dalam produk bahan ajar interaktif dinyatakan layak digunakan dengan revisi sesuai saran yang diberikan. Selanjutnya, proses validasi produk oleh dua ahli media. Hasil penilaian produk diperoleh rata-rata skor sebesar 3,22 dengan kategori sangat layak, sehingga produk bahan ajar interaktif dinyatakan layak digunakan sesuai dengan revisi yang disarankan ahli media.

Uji beta dilakukan setalah produk dinyakan layak oleh ahli. Uji beta dibagi menjadi dua tahap yaitu uji beta 1 (uji coba kelompok kecil) dengan melibatkan 6 orang siswa. Dari hasil penilaian respon uji beta 1 diperoleh rerata skor sebesar 3,22 yang secara kualitatif termasuk dalam kategori "sangat layak". Uji coba selanjutnya yaitu pada uji beta 2 (uji coba kelompok besar). Uji beta 2 (uji coba kelompok besar) diujicobakan kepada 32 siswa kelas X SMA PIRI 1 Yogyakarta. Rerata skor uji coba produk yang diperoleh uji beta 2 dengan rata-rata skor secara keseluruhan sebesar 3,19 dengan kategorikan sangat layak. Rata-rata skor tersebut menunjukkan respon siwa terhadap penggunaan produk bahan ajar interaktif pada pembelajaran.

Kelayakan produk bahan ajar interaktif dapat dicapai karena memenuhi kriteria penilaian produk bahan ajar interaktif terdiri dari keakuratan materi, learner control, materi sesuai dengan kurikulum, materi up to date, menggunakan bahasan yang jelas, dapat memabangkit motivasi siswa, siswa dapat berpartisipasi di dalamnya, memberikan petunjuk penggunaan (Heinich, Molenda, Russell, \& Smaldino, 1996, p. 47). Selain itu produk bahan ajar interaktif menerapkan kriteria multimedia menurut Alessi \& Trollip (2001 ,pp. 414-431) yaitu keluasan materi, urutan materi, kejelasan bahasa yang digunakan, kesesuaian materi dengan tujuan belajar, terdapatnya petunjuk belajar, kesimpulan/rangkuman, navigation dan interface dan adanya glossary. Selanjutnya kriteria penilaian bahan ajar interaktif didasarkan menurut Romiszowski (1986, pp. 406-407) yaitu materi divalidasi oleh ahli materi, didukung oleh media yang tepat, contoh dan latihan soal sesuai 
dengan tujuan belajar, dan tingkat kesulitan soal disesuaikan dengan kemampuan siswa. Selain didasarkan kriteria penilaian tersebut, produk bahan ajar interaktif juga menerapkan karakteristik modul yaitu (1) self instruction, (2) self contained, (3) stand alone, (4) Adaptive, (5) user friendly, dan 7 prinsip desain multimedia Mayer (2009, p. 3) untuk penyajian materi dalam bentuk animasi dan video. Prinsip-prinsip tersebut yaitu prinsip multimedia, prinsip keterdekatan waktu, prinsip koherensi, prinsip modalitas, prinsip redudansi, dan prinsip perbedaan individual.

Uji efektivitas produk dilakukan untuk mengetahui pengaruh produk yang dikembangkan terhadap pemahaman konsep. Berdasarkan hasil pretest dan posttest diperoleh nilai gain skor sebesar 0,71 . Skor gain yang diperoleh menunjukkan bahwa terjadi peningkatan pemahaman konsep dengan kategori tinggi.

Produk bahan ajar interaktif dinilai efektif dalam meningkatkan pemahaman konsep, karena materi yang disajikan selain menggunakan teks dan gambar, juga dilengkapi dengan animasi dan video materi yang memvisualisasi materi dimensi tiga. Hal tersebut didukung oleh pendapat Rogness (2011, p. 6), yang menyatakan bahwa penggunaan visualisasi dapat membantu siswa dalam meningkatkan pemahaman konsep. Bentuk visual tersebut dapat berupa animasi maupun video (Gambari, Falode, \& Adegbenro, 2014, p. 128). Hal ini tersebut juga didukung oleh dengan penelitian yang dilakukan oleh Lasmiyati \& Harta (2014, p. 162) bahwa bahan ajar berupa modul dapat meningkatkan pemahaman konsep.

Setelah melakukan uji coba dan kajian terhadap produk bahan ajar interaktif, terdapat beberapa aspek kelemahan dari produk tersebut di antaranya; (1) Produk bahan ajar interaktif di dalamnya terdapat latihan soal yang dikembangkan dengan software Ispring Suite 7, namun terkadang mengalami gangguan pada tampilannya. Dimana tampilannya dapat berubah posisi tergantung dengan spec komputer yang digunakan; (2) Bahan ajar interaktif belum didukung dengan pengunaan perangkat smartphone, hanya tersedia dalam bentuk format baca komputer ataupun laptop; (3) Produk bahan ajar interaktif file .exe hanya bisa dijalankan pada komputer dengan sistem operasi Windows yang memiliki spec tinggi dan apabila digunakan pada komputer yang memiliki spec rendah, maka produk bahan ajar interaktif tidak dapat dibuka. Hal ini disebabkan oleh besarnya ukuran file yang dihasilkan; (4) Bahan ajar interaktif belum didukung dengan adanya worksheet, hanya tersedia latihan soal berbentuk pilihan ganda.

\section{Simpulan}

Berdasarkan pada tujuan pengembangan, pertanyaan penelitian, dan hasil penelitian dan pengembangan dapat simpulkan bahwa produk bahan ajar interaktif adalah sebagai berikut: Pertama, Bahan ajar interaktif pada mata pelajaran matematika khususnya materi ruang dimensi tiga untuk siswa kelas X SMA PIRI 1 Yogyakarta yang dihasilkan dalam bentuk digital yang dikemas menggunakan Compact Disk (CD) dan dilengkapi dengan buku petunjuk yang dapat digunakan sebagai sumber belajar pendukung pembelajaran matematika. Produk bahan ajar interaktif yang dihasilkan, dilengkapi dengan konten teks, gambar, animasi dan video. Produk bahan ajar interaktif terdiri atas komponen-komponen yang mencakup; halaman sampul (cover), identitas modul, kata pengantar, daftar isi, glosary, sasaran pengguna, deskripsi, tujuan akhir pembelajaran, peta konsep, kriteria keberhasilan, isi memuat; (a) tujuan pembelajaran, (b) uraian materi, (c) rangkuman, (d) latihan soal, (e) daftar referensi, (f) kunci jawaban/pembahasan soal), dan Uji kompetensi. Latihan soal yang disajikan pada tiap kegiatan pembelajaran berupa soal pilihan ganda, yang bertujuan untuk mengukur pemahaman siswa terhadap materi yang telah dipelajari.

Kedua, Bahan ajar interaktif yang dikembangkan dinilai sangat layak diguna- 
kan sebagai salah satu sumber belajar pembelajaran matematika. Hal tersebut ditinjau berdasarkan hasil penilaian uji alpha (ahli materi dan ahli media) dan uji beta (respon siswa) sebagai berikut: (a) Hasil uji alpha yang dinilai oleh kedua ahli materi diperoleh rerata skor secara keseluruhan dari kelima aspek sebesar 3,15 dengan kategori "Sangat Layak", (b) Hasil uji alpha yang dinilai oleh kedua ahli media diperoleh rarata skor secara keseluruhan dari ketiga aspek sebesar 3,22 dengan kategori "Sangat Layak". (c) Hasil uji beta pada uji beta 1 (uji kelompok kecil) diperoleh rerata keseluruhan dari ketiga aspek sebesar 3,22 dengan kategori "Sangat Layak". Sedangkan hasil uji beta 2 (uji kelompok besar) diperoleh rerata skor secara keleluruhan dari ketiga aspek sebesar 3,19 dengan kategori "Sangat Layak".

Ketiga, Bahan ajar interaktif yang dikembangkan dinilai efektif dalam meningkatkan pemahaman konsep matematika siswa dilihat dari nilai rata-rata pretest sebesar 22,65 meningkat pada posttest sebesar 74,23 dengan nilai gain skor sebesar 0,71.

Adapun saran pemanfaatan produk bahan ajar interaktif agar lebih efektif dalam proses pembelajaran diantaranya sebagai berikut. Pertama, Guru terlebih dahulu menjelaskan tentang produk dan penggunaannya dengan tujuan agar siswa lebih mudah memahami materi yang disajikan dalam produk bahan ajar interaktif.

Kedua, dalam menyampaikan materi diawali dengan menyampaikan tujuan pembelajaran agar siswa dapat memiliki gambaran meteri sebelum belajar. Ketiga, penggunaan produk bahan ajar interaktif, sebaiknya guru menjelaskan kembali materi ataupun soal-soal latihan yang terdapat didalamnya. Keempat, siswa mempelajari keselurahan komponen yang terdapat dalam produk diawali dengan mempelajari daftar isi, petunjuk, kompetensi, uraian materi, latihan, kunci jawaban, dan uji kompetensi. Diskusikan dengan guru maupun teman sebaya apabila kesulitan dalam memahami materi ataupun menjalankan produk bahan ajar interaktif.
Kelima, siswa harus mempelajari dengan baik petunjuk-petunjuk dalam mengoperasikan produk bahan ajar interaktif, sehingga lebih mudah digunakan. Keenam, baik guru maupun siswa, untuk mengoperasikan produk bahan ajar interaktif sebaiknya menggunakan komputer/ laptop dengan spec sesuai dengan spesifikasi produk yang terdapat dalam buku petunjuk.

\section{Daftar Pustaka}

Alessi, S. M., \& Trollip, S. P. (2001). Multimedia for learning: methods and development (3rd ed.). Boston: Allyn and Bacon.

Degeng, I. N. S. (2013). Ilmu pembelajaran klasifikasi variabel untuk pengembangan teori dan penelitian. Bandung: Kalam Hidup.

Departemen Pendidikan Nasional. (2008). Panduan pengembangan bahan ajar. Jakarta: Ditjen Manajemen Dikdasmen.

Effiong, O. E., \& Igiri, C. E. (2015). Impact of Instructional Materials in Teaching and Learning of Biology in Senior Secondary Schools in Yakurr LG A. International Letters of Social and Humanistic Sciences, 62, 27-33. https:// doi.org/10.18052/www.scipr ess.com/ILSHS.62.27

Fajarini, A., Soetjipto, B. E., \& Hanurawan, F. (2016). Developing a social studies module by using problem based learning (PBL) with scaffolding for the seventh grade students in a junior high school in Malang, Indonesia. IOSR Journal of Research $\mathcal{E}$ Method in Education (IOSR-JRME), 6(1), 62-69.

Gambari, A. I., Falode, C. O., \& Adegbenro, D. A. (2014). Effectiveness of computer animation and geometrical instructional model on mathematics achievement and retention among junior secondary school students. European Journal of Science and 
Mathematics Education, 2(2).

Guido, R. M. D. (2014). Evaluation of a modular teaching approach in materials science and engineering. American Journal of Educational Research, 2(11), 1126-1130. https://doi.org/10.12691/education2-11-20

Hake, R. R. (1998). Interactive-engagement versus traditional methods: A sixthousand-student survey of mechanics test data for introductory physics courses. American Journal of Physics, 66(1), 64-74. https:// doi.org/10.1119/1.18809

Haryanto. (2015). Teknologi pendidikan. Yogyakarta: UNY Press.

Heinich, R., Molenda, M., Russell, J., \& Smaldino, S. (1996). Instructional media and technologies for learning.

Englewood Cliffs New Jersey: Prentice-Hall, Inc, Asimon \& Scuster Company.

Herawati, O. D. P., R., S., \& Basir, H. M. D. (2010). Pengaruh pembelajaran problem posing terhadap kemampuan pemahaman konsep matematika siswa kelas XI IPA SMA Negeri 6 Palembang. Jurnal Pendidikan Matematika, 4(1), 1-11.

Hernawan, A. H., Susilana, R., Julaeha, S., \& Sanjaya, W. (2011). Pengembangan kurikulum dan pembelajaran. Jakarta: Universitas Terbuka.

Ibrahim, \& Suparni. (2008). Strategi pembelajaran matematika. Yogyakarta: Bidang Akademik UIN Sunan Kalijaga.

Ifeoma, M. M. (2013). Use of instructional materials and education performance of student in integrated science (a case study of Unity Schools in Jalingo, Taraba state, Nigeria). IOSR Journal of Research \& Method in Education (IOSRJRME), 3(4), 07-11.

Jihad, A., \& Haris, A. (2008). Evaluasi pembelajaran. Jakarta: Multi Pressindo.

Kariadinata, R. (2010). Kemampuan visualisasi geometri spasial siswa Madrasah Aliyah Negeri kelas X melalui sioftware pembelajaran mandiri. Jurnal Edukasi Matematika, 1(2).

Kilpatrick, J., \& Swafford, J. (2001). Adding it up: helping children learn mathematics. (B. Findell, Ed.). Washington, DC: National Academy Press.

Lasmiyati, \& Harta, I. (2014). Pengembangan modul pembelajaran untuk meningkatkan pemahaman konsep dan minat SMP. Jurnal Pendidikan Matematika, 9(2), 161-174.

Lukman, L., \& Ishartiwi, I. (2014). Pengembangan bahan ajar dengan model mind map untuk pembelajaran ilmu pengetahuan sosial SMP. Jurnal Inovasi Teknologi Pendidikan, 1(2), 109122.

https:// doi.org/10.21831/tp.v1i2.252 3

Mardapi, D. (2008). Teknik penyusunan instrumen tes dan nontes. Yogyakarta: Mitra Cendikia Press.

Mawarni, S., \& Muhtadi, A. (2017). Pengembangan digital book interaktif mata kuliah pengembangan multimedia pembelajaran interaktif untuk mahasiswa teknologi pendidikan. Jurnal Inovasi Teknologi Pendidikan, 4(1), 84. https:// doi.org/10.21831/jitp.v4i1.10 114

Mayer, R. E. (2009). Multimedia learning (2nd ed.). New York: Cambridge University Press.

Merrill, M. D. (1994). Instructional design theory. New Jersey: Educational Technology Publication.

Mudlofir, A. (2011). Aplikasi pengembangan KTSP dan bahan ajar dalam pendidikan agama Islam. Jakarta: PT RajaGrafindo Persada. 
Munir, M. (2015). The use of multimedia learning resource sharing (MLRS) in developing sharing knowledge at schools. International Journal of Multimedia and Ubiquitous Engineering, 10(9), 61-68.

https://doi.org/10.14257/ijmue.2015. 10.9.07

National Council of Teachers of Mathematics. (2000). Principle and standards for school mathematics.

Nugent, G., A., K., C., D. N., Guretzky, J., Murphy, P., \& Lee, D. (2016). Learning from online modules in diverse instructional contexts. Interdisciplinary Journal of E-Skills and Life Long Learning, 12, 113-121.

Prastowo, A. (2011). Panduan kreatif membuat bahan ajar inovatif (Yogyakarta). DIVA Press.

Presiden Republik Indonesia. UndangUndang Republik Indonesia nomor 20 tahun 2003 tentang Sistem Pendidikan Nasional (2003). Indonesia.

Presiden Republik Indonesia. Peraturan Pemerintah Republik Indonesia Nomor 19 Tahun 2005 tentang Standar Nasional Pendidikan (2005).
Purmadi, A., \& Surjono, H. D. (2016). Pengembangan bahan ajar berbasis web berdasarkan gaya belajar siswa untuk mata pelajaran Fisika. Jurnal Inovasi Teknologi Pendidikan, 3(2), 151. https:// doi.org/10.21831/jitp.v3i2.82 85

Rogness, J. (2011). Mathematical visualitation. Journal of Mathematics Education at Teachers College, 2(FallWinter).

Romiszowski, A. J. (1986). Developing auto instructional materials. New York: Kogan Page Ltd.

Sartono, W. (2006). Matematika untuk siswa kelas X. Jakarta: Erlangga.

Sudjana, N., \& Rivai, A. (2002). Media pengajaran. Bandung: Sinar Baru Algensindo.

Sukiman. (2012). Pengembangan media pembelajaran. Yogyakarta: Pustaka Insan Madani.

Widodo, C. S., \& Jasmandi. (2008). Panduan menyusun bahan ajar kompetensi. Jakarta: PT Elex Media Komputindo. 